ISSN1027-5495. Functional Materials, 23, No.3 (2016), p. 490-495

doi:http://dx.doi.org/10.15407/fm23.03.490

(C) 2016 - STC “Institute for Single Crystals"

\title{
Use of amino-naphthoquinones for production of antimicrobial textiles
}

\author{
Hong Li, Chao Ding, Yingchao Ji, Ying Wang, Qiuhong Wang \\ School of Textile and Material Engineering, Dalian Polytechnic University, \\ Dalian, 116034, China
}

Received April 22, 2016

\begin{abstract}
This study described a method for enhancing the durability of amino-naphthoquinones embedded on cotton fabrics by creating aldehyde groups in the molecular structure of cotton cellulose. These aldehyde groups undergo intermolecular coupling with the amino group to form imines whereby naphthoquinones are covalently bonded to the cotton cellulose. The results suggest that these antibacterial compounds are tightly bound to the cotton fabric and impart to the fabric antibacterial properties, which retain their antibacterial activity after 15 laundry cycles. Such type of antimicrobial finish can find wide application in the health and hygiene textile sector.
\end{abstract}

Keywords: amino-naphthoquinones, sodium periodate, antibiotic finish, schiff base, cotton fabric

Описан способ повышения устойчивости аминонафтохинов, входящих в хлопковые ткани, путем создания альдегидных групп в молекулярной структуре хлопковой целлюлозы. Полученные результаты свидетельствуют о том, что указанные антибактериальные соединения тесно связаны с хлопковой тканью, они придают ткани антибактериальные свойства, которые сохраняют свою антибактериальную активность даже после 15 циклов обработки. Такой тип антибактериальной обработки может найти широкое применение в здравоохранении и в гигиеническом секторе текстильной отрасли.

Використання амінонафтохінонів для виробництва антибактеріального текстилю. Хун Лі, Чао Дін, Інг Чао Лі, Ін Ван, Цю Хун Ван

В роботі описано спосіб підвищення міцності вбудованих в бавовняні тканини амінонафтохінонов шляхом створення альдегідних груп в молекулярній структурі бавовняної целюлози. Отримані результати свідчать про те, що зазначені антибактеріальні сполуки тісно зв'язані з бавовняною тканиною, вони надають тканині антибактеріальні властивості, які зберігають свою антибактеріальну активність навіть після 15 циклів обробки. Такий тип антибактеріальної обробки може знайти широке застосування в охороні здоров'я і в гігієнічному секторі текстильної галузі.

\section{Introduction}

Compounds containing amino-naphthoquinones contribute greatly to some commercially important pharmaceuticals[1]. A number of inhibitory activities have been associated to naphthoquinones, such as antifungal, antiparasitary, anticancer, antiviral and antibacterial effects. There are so many articles reported their therapeutic benefits[2]. We now wish to present the application of synthesizing derivatives of amino-naphthoquinones as effective antibiotic finishes on cotton fabric.

The durability of the antimicrobial agents during their use is the major issue in the production of antibacterial textiles. Although the compounds of amino-naphthoquinones show excellent antimicrobial properties, they are still not antimicrobial finishing agents and not bind to fabrics. Therefore, permanent binding 
<smiles>NC1=CC(=O)c2ccccc2C1=O</smiles><smiles>NC1=C(O)C(=O)c2ccccc2C1=O</smiles>

Compound 1

Compound 2<smiles>COC1=C(N)C(=O)c2ccccc2C1=O</smiles>

Compound 3

Fig. 1. Synthesis of amino-naphthoquinones

of the antibacterial amino-naphthoquinones to the textile material is highly desirable.

Alternatively, controlled oxidation of cotton fabrics with sodium periodate can modify the cellulose embracing aldehyde groups in addition to the primary and secondary hydroxyl groups[3].

Such modification of cotton fabrics would couple with amino group producing imines, and thus ensure durability of the antibacterial effect of 1,4-naphthoquinone analogs during exploitation. In the present study, we have carried out antibacterial efficacy tests of biomimetic synthesis derivatives

of 1,4-naphthoquinone, whose structures are shown in Fig. (1).

\section{Experimental}

\subsection{Materials}

The strains screened for antibacterial activity were clinical isolates obtained from School of Biological Engineering of Dalian Polytechnic University. Deionized water was used for all preparations and all chemicals were used without further purification. Bleached woven 100\% cotton fabric obtained from DLPU (China) was used in the study.

\section{Synthesis of Amino-naphthoquinones}

Preparation of 2-hydroxy-3-nitro-1,4-naphthoquinone.

A mixture of concentrated sulfuric acid $(25 \mathrm{ml})$ and nitric acid $(8 \mathrm{ml})$ was added to a stirred suspension of 2-hydroxy-1,4-naphthoquinone $(8.4 \mathrm{~g})$ in chloroform $(100 \mathrm{ml})$. After stirring for 0.5 hour at $15^{\circ} \mathrm{C}$, The mixture was poured into ice, and an abundant separation of very fine yellow needles took place. The crude reaction mixture was washed with hydrochloric acid for several times. Filtration gave the crude yellow product. On recrystallization twice from the acetic acid pure substance was obtained in beautiful, fine yellow needles.

FTIR (KBr) $\left(\mathrm{cm}^{-1}\right): 3317(\mathrm{OH}), 1688,1651$ $(\mathrm{C}=\mathrm{O}), 1536,1334$ (NO2) ;

${ }^{1} \mathrm{H}$ NMR (300 MHz, CDCl3): $\delta$ 7.82-7.96 (m, $2 \mathrm{H}), 8.19-8.26$ (m, $2 \mathrm{H}), 8.68(\mathrm{~s}, 1 \mathrm{H})$;

${ }^{13} \mathrm{C}$ NMR (75 MHz, DMSO): $\delta$ 126.3, 131.0, 132.3, 133.4, 135.0, 135.4, 136.7, 161.9, 172.0, 184.0.

\section{2-hydroxy-3-Amino-1,4-naphthoquinone}

A solution of stannous chloride (13.5 g) in concentrated hydrochloric $(20 \mathrm{ml})$ acid was added to 2-hydroxy-3-nitro-1,4-naphthoquinone (2 g) in ethanol. The reaction mixture was heated to boiling for $10 \mathrm{~min}$, the color changed from yellow to brown. When the mixture was cooled, the product need not be isolated but reoxidized directly in the same medium by adding $3 \mathrm{~g}$ of hydrogen peroxide. The resulting reactionmixture was stirred for 10 min during the brown solution turned into a dark red solution. The product of 2-hydroxy-3-Amino-1,4-naphthoquinone was obtained after dried over anhydrous sodium sulfate and concentrated in vacuo.

FT-IR (cm-1): 3480 (OH), 3390 (NH2), $1660,1650(\mathrm{C}=\mathrm{O})(\mathrm{KBr})$;

${ }^{1} \mathrm{H}$ NMR (300 MHz, CDCl3): $\delta 7.99(1 \mathrm{H}, \mathrm{dd}$, J 6.9 and $3.3 \mathrm{~Hz}, \mathrm{H} 5), 8.05$ (1H, dd, J 6.9 and $3.3 \mathrm{~Hz}, \mathrm{H} 8), 7.62(1 \mathrm{H}$, dt, J 6.9 and $2.4 \mathrm{~Hz}, \mathrm{H} 6)$, $7.72(1 \mathrm{H}$, dt, J 6.9 and $2.4 \mathrm{~Hz}, \mathrm{H} 7)$;

${ }^{13} \mathrm{C}$ NMR (75 MHz, CDCl3): $\delta 177.0$ (C1), 135.9 (C2), 133.2 (C3), 181.4 (C4), 130.3 (C4a), 125.1 (C5 ), 132.5 (C6), 133.8 (C7), 124.9 (C8), 131.0 (C8a).

2-Amino-1,4-naphthoquinone and 2-Amino-3-metho- xy-1,4- naphthoquinone

2-Amino-1,4-naphthoquinone and 2-amino3-methoxy-1, 4-nap hthoquinone were synthesised as described in Ref[4] and [5]. The structures were determined by IR and NMR.The dates are the following:

2-amino-1,4-naphthoquinone:

FTIR $(\mathrm{KBr}) \quad\left(\mathrm{cm}^{-1}\right): \quad 3370(\mathrm{NH} 2), \quad 1685$, $1645(\mathrm{C}=\mathrm{O})$;

1H NMR (300 MHz, CDCl3): $\delta 5.10(\mathrm{~s}, 2 \mathrm{H})$, $5.93(\mathrm{~s}, 1 \mathrm{H}), 7.55-7.59(\mathrm{~m}, 1 \mathrm{H}), 7.64-7.68(\mathrm{~m}$, $1 \mathrm{H}), 7.98-8.02(\mathrm{t}, 2 \mathrm{H})$;

13C NMR (75 MHz, CDCl3): $\delta 105.2,126.2$, 126.3, 130. 5,132.3, 133.4, 134.6, 148.3, 181.9, 183.8 .

2-amino-3-methoxy-1,4-naphthoquinone:

FTIR $(\mathrm{KBr})\left(\mathrm{cm}^{-1}\right):$ 3425(NH2), 2948(CH3), 1670, $1638(\mathrm{C}=\mathrm{O})$;

1H NMR (300 MHz, CDCl3): $\delta 4.00(\mathrm{~s}, 3 \mathrm{H})$, $5.08(\mathrm{~s}, 2 \mathrm{H}), 7.54-7.58(\mathrm{~m}, 1 \mathrm{H}), 7.63-7.67(\mathrm{~m}$, $1 \mathrm{H}), 7.93-7.96(\mathrm{~m}, 1 \mathrm{H}), 8.00-8.03(\mathrm{~m}, 1 \mathrm{H})$;

13C NMR (75 MHz, CDCl3): $\delta 59.92,125.31$, $125.55,129.74,131.70,131.83,133.88,137.06$, 138.51, 177.95, 181.57. 


\subsection{Modification of Cotton Fabric with Sodium Periodate}

Cotton fabric was immersed in solution of sodium acetate buffer with sodium periodate in deionized water at room temperature. The solution was then stirred at $60 \mathrm{rpm}$ in the absence of light. Thereafter the fabric was washed clean with deionized water several times and soaked in deionized water at room temperature for the next reaction without drying.

\subsection{Bonding the Amino-naphthoqui- nones to the Oxidized Cotton Fabric}

The amino-naphthoquinone compounds, dissolved in methanol, were added stirring to a solution of acetic acid in water. The oxidized cotton fabrics were immersed in the aqueous solution of aminonaphthoquinone under proper conditions. Then these cotton samples treated with amino-naphthoquinones were cleaned with detergent for several times and dried at room temperature. This operation led to the antibiotic finishes carrier cotton fabric whereby naphthoquinones are covalently bonded to the cotton cellulose.

\subsection{Assessment of Antibacterial Activity}

Samples including treated fabrics and untreated fabrics were sterilised in an autoclave for $15 \mathrm{~min}$ at $120^{\circ} \mathrm{C}$. Two bacterial species, Gram-positive Staphylococcus aureus (ATCC No. 6538), and Gram-negative Klebsiella pneumonia (ATCC No. 4352) were used throughout the experiment. Lyophilized bacteria were grown in trypticase soy broth (TSB) at $37^{\circ} \mathrm{C}$ and $100 \mathrm{rpm}$. In order to get the pure strains, subcultures were incubated from this suspension on fresh sterile TSB after 24 hours at $37^{\circ} \mathrm{C}$ and $100 \mathrm{rpm}$.

QualitativeTest - AATCC Test Method 1472004

$24 \mathrm{~h}$ TSB cultures of the test organisms (Klebsiella pneumonia and Staphylococcus aureus) were used as inocula. Sterile bacteriostasis agar was dispensed in petri plates. Using a $4 \mathrm{~mm}$ inoculating loop, load one loop full of the diluted inoculum and transfer to the surface of the sterile agar plate by making five streaks approximately $60 \mathrm{~mm}$ in length, spaced $10 \mathrm{~mm}$ apart covering the central area of a standard petri dish without refilling the loop. Test specimens (control \& treated fabric) were cut with a rectangular die $(25 \times 50 \mathrm{~mm})$ and were placed to inoculated TSB transversely across the five inoculum streaks. The plates were incubated at $37^{\circ} \mathrm{C}$ for 24 hours. Examine the incubated plates for interruption of growth along the streaks of inoculum beneath the specimen and for a clear zone of inhibition beyond its edge. The average width of a zone of inhibition along a streak on either side of the test specimen may be calculated using the following equation:

$$
W=(T-D) / 2
$$

where:

$W$ - width of clear zone of inhibition in $\mathrm{mm}$

$T$ - total diameter of test specimen and clear zone in $\mathrm{mm}$

$D$ - diameter of the test specimen in $\mathrm{mm}$

Quantitative Tests-AATCC Test Method 100-2004

The bacteria were suspended at a known approximate concentration of bacterium that is $1.5 \times 105 / \mathrm{ml}$, was treated with the $4.8 \mathrm{~cm}$ diameter test fabric separately and incubated with 1 $\mathrm{ml}$ TSB in a volumetric flask at $37^{\circ} \mathrm{C}$ for $24 \mathrm{~h}$. Serially quenched were made with $100 \mathrm{ml}$ distilled water after shaken vigorously for $1 \mathrm{~min}$. The eluents were then diluted with saline solution. From each of dilutions, $0.1 \mathrm{ml}$ liquid was drawn and transferred to TSB further incubated at $37^{\circ} \mathrm{C}$ for $24 \mathrm{~h}$. The number of survivors was counted using an automatic colony counter. The reduction of colonies was calculated using the following equation:

$$
R=100 \times(B-A) / B,
$$

$R$ - percentage reduction

$A$ - the number of bacteria recovered from the TSB inoculated with treated test fabric sample after the desired contact period (24 hours)

$B$ - the number of bacteria in the TSB inoculated with treated test fabric sample immediately after inoculation

\section{Results and discussion}

Synthesis of The Derivatives of 1,4- Naphthoquinone

2-hydroxy-3-nitro-1,4-naphthoquinone was obtained by nitrating 2-hydroxy-1,4-naphthoquinone with nitric acid in the presence of sulfuric acid and then pouring the reaction mixture into an aqueous medium to precipitate the product. The reduction of aryl nitro in the presence of carbonyl with stannous chloride led to the formation of 2-amino-1,2,4-trihydroxynaphthalene, which was not isolated but reoxidized in the same medium by hydrogen peroxide to give 2-amino-3-hydroxy-1,4-naphthoquinone. The reaction mechanism is summarized in Fig.(2).

It is known that molecules with quinonoid moiety show tautomerism [6]. Therefore, for compound 2 we can suggest formation of two structures as follow:<smiles>NC1=C(O)C(=O)c2ccccc2C1=O</smiles>

A<smiles>NC1=C(O)c2ccccc2C(=O)C1=O</smiles>

B 


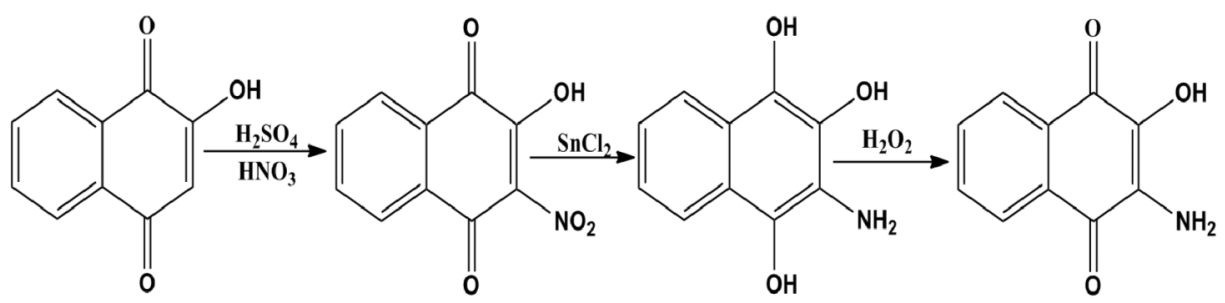

Fig. 2. The reaction mechanism of 2-amino-3-hydroxy-1,4-naph-thoquinone

To determine the structure of compound 2 , we measured its ultraviolet spectra. In the UV range, the chromophore in the $262 \mathrm{~nm}$ and in the region $245-338 \mathrm{~nm}$, characteristic for quinonoid ring of 1,4-naphthoquinone and benzenoid ring, respectively. The the absorption peak of the IR spectra at $3480 \mathrm{~cm}^{-1}$ was due to stretching vibration of hydroxyl. A band at $3390 \mathrm{~cm}^{-1}$ can be assigned to the -NH2 stretching vibrations. Absorption bands appearing at $1660 \mathrm{~cm}^{-}$ ${ }^{1}$ and $1650 \mathrm{~cm}^{-1}$ are characteristic of carbonyl stretching of 1,4-naphthoquinone. Thus, reactions of 2-amino-1,2,4-trihydroxynaphthalenne with hydrogen peroxide yield 2-amino-3-hydroxy-1,4-naphtho- quinone only. According to the ultraviolet spectra, we can see that the Compound 1 with electron-donating substituent (NH2) at the position 3 exhibits a pronounced bathochr- omic shift, its wavelength maxima is $443 \mathrm{~nm}$ in water while Compound 2 absorbs at $517 \mathrm{~nm}$ and compounds 3 at $503 \mathrm{~nm}$ in the same solvent.

Mechanism of the sodium periodate treatment and its influence on the cotton sample.

Cellulose is a linear polymer of D-glucose molecules. Two adjacent glucose units are linked by elimination of one water molecule between their hydroxyl groups at carbon atoms $\mathrm{C}_{1}$ and $\mathrm{C}_{4}$. When sodium periodate applied to cellulose, the adjacent hydroxyl groups at $\mathrm{C}_{2}$ and $\mathrm{C}_{3}$ positions are converted to aldehydes. The resulting aldehyde group on the cellulose would possess the ability to couple with an amino group of naphthoquinones, giving the so-called Schiff base. A simplified mechanism for oxidization of cellulose is illustrated in Fig.(3).

Although the oxidation of cotton fabrics with sodium periodate may cause loss in mechanical strength of the fabrics, however, a controlled oxidation of cotton fabrics with sodium periodate results in only moderate weight and strength losses. A weight loss of $1.5-2.5 \%$ is not considered detrimental for the tensile strength of the fabric. So oxidation with $5 \%$ o.w.f. sodium periodate was selected because it gave rise to an acceptable weight and strength losses in the fabrics.

Copper number determination was used to calculate the quantity of the aldehyde content present in the oxidized cotton[7]. A simplified mechanism for determination of aldehyde group quantity is illustrated as follow:

$$
\begin{aligned}
& \text { Cell- } \mathrm{CHO}+2 \mathrm{CuSO}_{4}+2 \mathrm{H}_{2} \rightarrow \\
& \text { Cell- } \mathrm{COOH}+2 \mathrm{H}_{2} \mathrm{SO}_{4}+\mathrm{Cu}_{2} \mathrm{O}
\end{aligned}
$$

By applying this method, the aldehyde grous content was calculated by subtracting the aldehyde content value determined in the starting cotton sample from the oxidized cotton samples. Under the condition which mentioned above ( $5 \%$ o.w.f. sodium periodate, material-to-liquor ratio 1:20,3h and $\mathrm{pH} 9.5$ ), the amount of aldehyde groups was $59 \mathrm{mmol} / \mathrm{g}$ cellulose, while $29 \mathrm{Mmol} / \mathrm{g}$ cellulose in the unmodified cotton (The end units of the cellulose has an aldehyde group).

Investigation of the treated oxidation cotton fabric with naphthoquinone

In the IR spectra of treated oxidized cotton with amino-naphthoquinones in the range $1631-1657 \mathrm{~cm}^{-1}$ can be assigned to the $\mathrm{C}=\mathrm{N}$ stretching vibrations. This function group was related closely to the covalent bond formation between the oxidation cotton fabric and naphthoquinone. Thus, reactions of the oxidized cotton with amino-naphthoquinones yield corresponding azomethines. By linking the azomethine structure to the oxidized cotton could improve the durability of the antimicrobial performance of amino-naphthoquinones. The reaction mechanism is given in Fig.(4).

Naphthoquinones are those compounds which contain conjugated systems as chromophore. So the percentage of the amino-naphthoquinones linked to the fabric can be determined by ultraviolet-visible (UV-VIS) spectrophotometer measurem- ent at the maximum wavelength of the amino-naphthoquinon- es used. The percentage of amino-naphthoquinones coupled with the modified cotton fabrics can be calculated with the following equation:

$$
\begin{gathered}
\text { Percentage of coupling }(\%)= \\
\left(A_{0}-A_{t}\right) / A_{0} \times 100
\end{gathered}
$$

Where the $A_{0}$ and $A_{t}$ are absorbance values at maximum wavelength measured before and after chemical reaction, respectively. 


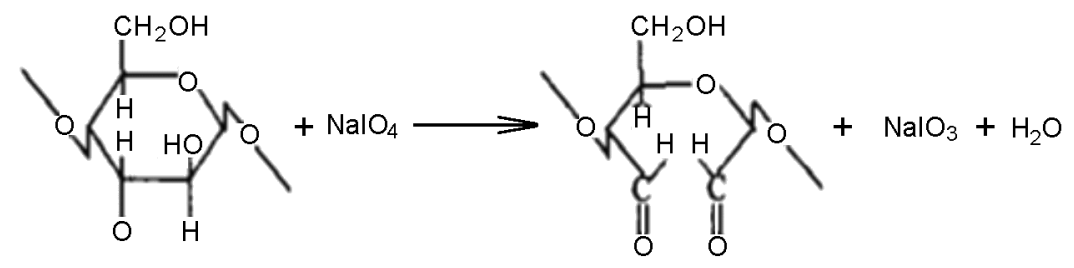

Fig. 3. The mechanism for oxidization of cotton cellulose.

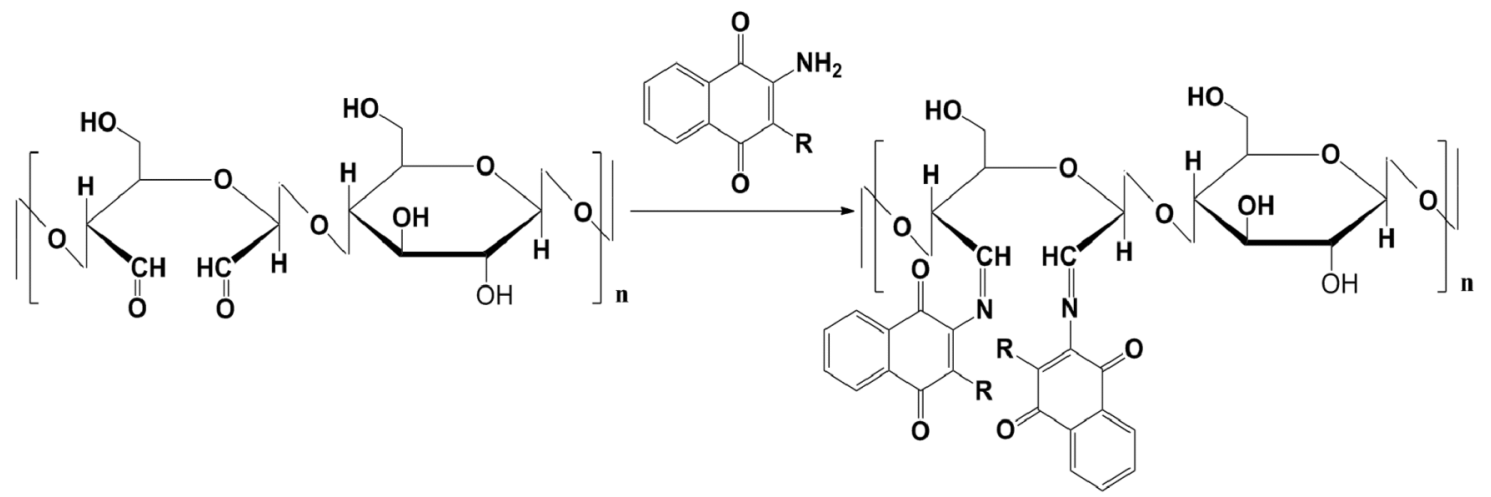

Fig. 4. Chemical reaction between oxidized cellulose and amino-na- phthoquinone

To find out the optimum condition required for best degree of exhaustion of amino-naphthoquinones, various of significant factors were investigated by orthogonal design and analysis of variance. The optimum process conditions have been tabulated in Table 1 .

Antibacterial activity and washing stability of the finished fabric

The mechanism of fighting against microorganisms using amino-naphthoquinones has been elucidated in detail in a previous publication [8-10]. In brief, the amino-naphthoquinones inhibits growth of microorganisms by using an electrochemical mode of action to penetrate and disrupt their essential structures. When the cell walls are penetrated, nucleic acid and ATP synthesis are inhibited by interfering with the electron transport chain of mitochondria, thereby preventing the organism from functioning or reproducing.

In the present study, AATCC test method 147-2004 and AATCC 100-2004 test method were used to examine fabrics functionalized with amino-naphthoquinones in view of antibacterial activity. AATCC $147-2004$ is suitable for demonstrating bacteriostatic activity by the diffusion of the antibacterial agent. AATCC 100-2004 is used to quantitatively measure the bacteriostatic of a product contaminated with the challenge bacteria. Additionally, this method is performed after multiple preconditioning procedures like washing or temperature cycling to simulate a product life-cycle.

According to the AATCC standard used for the testing, the minimum level of antibacterial activity that is deemed acceptable as effective is no growth under specimen in the contact area for parallel streak method. In this sense, all the treated fabric had showed acceptable antibacterial activity for both S. aureus and K. pneumoniae. The quantitative bacterial reduction was studied by percentage reduction test and the results of this percentage reduction test correspond with that of parallel streak method. The results revealed that antibacterial activity of tested fabrics against Gram positive

Table 1. The optimum condition for best degree of exhaustion of naphthoquinones

\begin{tabular}{|c|c|c|c|c|c|c|}
\hline Synthesis & $\begin{array}{c}\text { Tempera- } \\
\text { ture }\left({ }^{\circ} \mathrm{C}\right)\end{array}$ & $\begin{array}{c}\text { Time } \\
(\mathrm{min})\end{array}$ & Bath Ratio & $\mathrm{pH}$ & $\begin{array}{c}\text { Concentration } \\
(\% \text { o.w.f) }\end{array}$ & $\begin{array}{c}\text { Percentage } \\
\text { of coupling }\end{array}$ \\
\hline Compound 1 & 85 & 45 & $50: 1$ & 6.5 & $3 \%$ o.w.f & $71 \%$ \\
\hline Compound 2 & 75 & 30 & $50: 1$ & 6 & $3.2 \%$ o.w.f & $88 \%$ \\
\hline Compound 3 & 80 & 70 & $50: 1$ & 6.5 & $3.6 \%$ o.w.f & $83 \%$ \\
\hline
\end{tabular}


Hong Li et al. / Use of amino-naphthoquinones for production ...

Table 2. Antibacterial properties of treated fabric according to AATTC test method 147-2004

\begin{tabular}{|c|c|c|c|c|c|c|c|c|c|}
\hline \multirow{2}{*}{$\begin{array}{c}\text { No. of } \\
\text { washing } \\
\text { cycles }\end{array}$} & \multicolumn{2}{|c|}{ Control } & \multicolumn{3}{c|}{1} & \multicolumn{2}{c|}{2} & \multicolumn{2}{c|}{3} \\
\cline { 2 - 10 } & \multicolumn{7}{|c|}{ Inhibition zone, mm } \\
\hline & S. (mm) & K & S. & K. & S. & K. & S. & K. \\
\hline 0 & - & - & 0.9 & 0.6 & 1.9 & 1.6 & 1.3 & 1.2 \\
\hline 5 & - & - & 0.7 & 0.4 & 1.5 & 1.2 & 0.9 & 0.8 \\
\hline 10 & - & - & 0.3 & 0.1 & 0.9 & 0.8 & 0.7 & 0.5 \\
\hline 15 & - & - & 0.1 & 0 & 0.5 & 0.3 & 0.5 & 0.3 \\
\hline
\end{tabular}

Table 3. Antibacterial properties of treated fabric according to AATTC test method 100-2004

\begin{tabular}{|c|c|c|c|c|c|c|}
\hline \multirow{2}{*}{\begin{tabular}{c} 
No. of $\begin{array}{c}|c| \\
\text { washing } \\
\text { cycles }\end{array}$ \\
\cline { 2 - 7 }
\end{tabular}} & \multicolumn{5}{|c|}{2} & \multicolumn{2}{c|}{3} \\
\cline { 2 - 7 } & S. & K. & S. & K. & S. & K. \\
\hline 0 & 49.2 & 41.6 & 96.3 & 92.3 & 93.2 & 90.4 \\
\hline 5 & 45.7 & 40.3 & 94.2 & 90.3 & 92.3 & 87.3 \\
\hline 10 & 44.5 & 37.2 & 93.5 & 88.7 & 90.5 & 86.5 \\
\hline 15 & 42.6 & 35.6 & 92 & 85.6 & 89.7 & 85.7 \\
\hline
\end{tabular}

Data are mean of three independent experiments.

cocci was greater than that against Gram negative rods. This resistance may be attributed to the negative bacteria have very complicated cell walls structure, which not easily accessible to foreign molecules.

One of the characteristics of an ideal antibacterial textile is the durability of the antimicrobial agents, which is not lost during usage or washing. Therefore, in the present study, the antibacterial activity of washed fabrics was also evaluated.

Table 2 and Table 3 clearly showed that the significant antimicrobial activity was actively retained in the treated fabrics up to 15 washes at $60 \mathrm{eC}$. This is due to that amino-naphthoquinones designed have greater affinity for the fabric than water from which it is applied, thus resulting the antimicrobial finishing agents do not migrate off from the treated fabric and not lose their effectiveness. When the microbes contact with the surface of the treated cloth, they would be destroyed or inhibited continuously by acting on their essential structures.

\section{Conclusions}

In the research, three types of amino-naphthoquinone were prepared and were covalently bonded to the aldehyde cotton fabrics in order to impart antibacterial properties. The cotton fabrics were oxidative modification by using sodium periodate and almost no loss in weight, and have enough strength to support its use after modification. The results show that compound 2 and compound 3 have higher antibacterial activity that against Klebsiella pneumonia and Staphylococcus aureus both in qualitative and quantitative tests than compound 1 . The treated cotton fabric displayed antibacterial properties after 15 laundries at $60^{\circ} \mathrm{C}$. All the study indicated that the application of antimicrobial finishes to textiles by using aminonapgthquinones can be recommended and have much more values.

\section{References}

1. Kevin W. Wellington, N.I. Kolesnikova. Bioorg. Med. Chem., 20, 4472, 2002.

2. L.F.C. Medina, V. Stefani, A. Brandelli1, Lett. Appl. Microbiol., 42, 381, 2006.

3. A.J. Varma, M.P. Kulkarni., Polym. Degrad. Stab.,77, .25, 2002

4. Liu, Bing, Shun-Jun Ji, Synth. Commun., 38, 1201, 2008.

5. U.S. Patent No.20,150,073,177.

6. Dei, A., Gatteschi, D., Sangregorio, C., Sorace, Account. Chem. Res. .37, 827, 2004.

7. Geake, J.Text. Inst. Trans., 15, T27, 2008.

8. Thiago de Moraes, M.J. Filha, C.A. Camera, et al. Molecules, 19, 13188, 2014.

9. Medina,Luis FC, Valter Stefani, Adriano Brandelli, Can. J. Microbiol. 50, 951, 2004.

10. V. Ambrogi, D. Artini, I. de Carneri, et al., Br. J. Pharmocol.,40, 871, 1970. 